Article

\title{
Governance and the Gulf of Mexico Coast: How Are Current Policies Contributing to Sustainability?
}

\section{Stephen Jordan * and William Benson}

National Health and Environmental Effects Research Laboratory, Office of Research and Development, USA Environmental Protection Agency, 1 Sabine Island Drive, Gulf Breeze, FK 32541, USA

* Author to whom correspondence should be addressed; E-Mail: jordan.steve@epa.gov; Tel.: +1-850-934-9350; Fax: +1-850-934-9201.

Received: 23 August 2013; in revised form: 23 October 2013 / Accepted: 30 October 2013/ Published: 7 November 2013

\begin{abstract}
The quality of life and economies of coastal communities depend, to a great degree, on the ecological integrity of coastal ecosystems. Paradoxically, as more people are drawn to the coasts, these ecosystems and the services they provide are increasingly stressed by development and human use. Employing the coastal Gulf of Mexico as an example, we explore through three case studies how government policies contribute to preventing, mitigating, or exacerbating the degradation of coastal ecosystems. We consider the effectiveness of the current systems, what alternate or additional policy solutions might be needed to ensure the sustainability of the region and its quality of life, and what this example can tell us about the sustainability of coastal systems globally. In our examples, among other aspects, policies that are proactive and networked governance structures are observed to favor sustainable outcomes, in contrast to reactive policies and hierarchical models of governance.
\end{abstract}

Keywords: Tampa Bay; Coastal Louisiana; marine fisheries; governance networks

\section{Introduction}

In coastal communities, there is increasing acknowledgment that coastal resource management must evolve if we are going to protect the environment and safeguard human health into the future [1]. Practices that were acceptable in the past, such as permitting intensive development of barrier islands, will not be acceptable in the future, in large part because they will not be sustainable. Changes surely 
will occur in the choices made by individuals, in the solutions implemented by government, in the role that communities play in local decision-making, and the mechanisms of environmental governance. Improved understanding of sustainability and the interconnections between human health and ecological integrity will aid society in seeking an acceptable standard of living for coastal communities, while ensuring that the ecological services on which society depends are protected and are, themselves, sustained. We suggest that coastal communities will need to integrate social and natural systems on a local scale, while understanding the broader consequences on a regional or national scale. Knowledge of the three pillars of sustainability (environment, economy, and society), and their interactions, must be adequate to inform policy and decision-making by coastal communities. Indeed, we postulate a fourth pillar or dimension of sustainability that merits attention: time, i.e., sustaining natural resources and ecosystem services to support viability and quality of life for future generations. Further, the world is dynamic, so a sound understanding of sustainability must recognize the need for adaptability and resilience to change [2,3] as well as the advantage of proactive, protective policies over reactive attempts to restore lost natural resources and environmental values.

Understanding the potential for change in coastal ecosystems is essential not only to the environmental pillar of sustainability, but also to the economic and social components. The natural system, along with the economic and social counterparts, shapes and influences the well-being of individuals, societies, and ecosystems, both now and in the future [4]. For the individual, meeting basic needs such as food, shelter, and health maintenance is a prerequisite to economic and social well-being. These needs are met through adequate access to health care, employment, and educational opportunities. Well-being for ecological systems could also be defined using concepts similar to those that define well-being for humans. The quality and quantity of habitats, including all facets required for survival, maintenance, and proliferation of populations and ecological functions, are analogous to human well-being. Although nonhuman species and their ecological systems are unlikely to be aware of their own well-being to the degree that humans are, drawing this parallel between well-being of humans and nonhumans fosters recognition of the interconnections among the natural, economic and social components of sustainability [4]. If, for example, a major power plant or toxic waste repository is sited in an area that has a potential for episodic system change (e.g., major hurricane, flooding), there are strong implications for both economics and society [5]. More gradual changes that fall within the capacity of ecosystems may test the limits of adaptability of societies and may incur significant economic costs to cope with these changes. The challenge for decision makers is that the majority of environmental decisions fall into a middle ground where science plays a bounded but critical role and values and preferences, often strong and initially polarized, are also critical but not fixed [6]. One of the most prominent examples of gradual environmental change is sea level rise, which poses serious and increasing risks for coastal ecosystems and communities.

\section{Decision Environment for Coastal Resource Management in the Gulf of Mexico}

The decision environment for managing the coastal zone can be characterized by the policies, regulatory requirements, and capabilities of various agencies depending upon the context and scale of the decision [7,8]. The many agencies involved have mandates that can be complementary, overlapping, or conflicting. Thus, under the existing authorities, knowing what is feasible for the 
decision-makers in a decision context provides a foundation for understanding what can be achieved and what means are possible for achieving it. Moreover, it is understood that the decision context for coastal resource management must include a wide and complex mix of governance processes with stakeholders and special interest groups.

In the near term, the most feasible options depend upon policies and strategies that can be implemented given existing legislative and governance structures [9]. We examine whether this is a recipe for sustainability, or whether different models might better serve the future of ecological and human well-being. We ask how current structures might be adapted to new challenges rather than proposing an (unlikely) major restructuring of law and governance (but see [3]). After presenting an overview of federal, state, local and regional authorities and organizations, we examine these questions through three examples with widely different challenges and spatial scales: Tampa Bay, coastal Louisiana, and coastal marine fisheries. To elicit principles of governance underlying the contrasts between these examples, we employ comparative analysis, a technique used by historians to draw causal inferences from similarities or contrasts between small numbers of cases [10].

The Gulf of Mexico covers more than 617,600 square miles (1.6 million $\mathrm{km}^{2}$ ), connecting with several major river systems and many coastal communities. The Gulf is bounded to the east, north, and west by five USA states, by Mexico to the southwest, and by Cuba to the southeast; we limit our discussion to the USA coast. Gulf coastal estuaries, bays, and sub-estuaries cover 10,643 square miles $\left(27,565 \mathrm{~km}^{2}\right)$, framed by an extensive system of barrier islands. Gulf coast estuaries and wetlands are critical feeding, spawning, and nursery habitats for a rich assemblage of fish and wildlife, including essential habitat for shorebirds, colonial nesting birds, migratory waterfowl, and nurseries for diverse recreational and commercial fishery species. Increasing population pressures translate into increased use of and demands on Gulf coastal resources; from 1970 to 2000, the population of coastal zone counties nearly doubled [7]. A major socio-economic dilemma is that huge investments in restorative and protective measures, as well as new infrastructure, continue to be made in increasingly vulnerable coastal areas where the investments are unlikely to be sustainable. In the absence of human development, ecosystems tend to be resilient to environmental changes, although rapid sea level rise, ocean acidification, and other factors associated with climate change are challenging their resilience and adaptability. Yet, even in the face of these environmental pressures, socioeconomic interests often prevail over fully sustainable approaches to develop, protect, and restore the coastal zone.

\subsection{The Federal Role}

The USA Government affects the sustainability of environmental resources and human well-being through a variety of agencies, statutory mandates and discretionary programs. Of major relevance to the Gulf Coast, Federal policies, regulations, and management programs apply to human health, safety and welfare, water and air quality, waste management, marine fisheries, endangered species, fossil fuel extraction, oil pollution, ocean dumping, ports and waterways, and public access to beaches (Table 1). In some cases (e.g., water quality and public access), federal policies are administered by the states; in others (e.g., air quality) by national mandates, and yet others (e.g., marine fisheries) through multi-state regional entities. 
Table 1. Federal USA agencies, statutes, and programs with major roles in the Gulf of Mexico coastal zone. This list is not inclusive; many other agencies, statues and programs have relevant, but less prominent roles (see [11] for a more complete account). $\S(\S)=\operatorname{Section}(\mathrm{s})$.

\begin{tabular}{|c|c|}
\hline Lead Agency & Policies and programs \\
\hline \multirow{4}{*}{$\begin{array}{l}\text { Environmental Protection } \\
\text { Agency (EPA) }\end{array}$} & $\begin{array}{l}\text { Clean Air Act (CAA), } 42 \text { USC } \S \S 7401-7671 q \text { and } 1990 \text { Amendments. } \\
\text { Through National Ambient Air Quality Standards, establishes the } \\
\text { maximum permissible concentrations of major air pollutants. }\end{array}$ \\
\hline & $\begin{array}{l}\text { Clean Water Act (CWA), } 33 \text { USC } \S \S 1251-1387 \text {, is for the purpose of } \\
\text { restoring and maintaining the chemical, physical, and biological integrity } \\
\text { of the Nation's waters and requires that all US waters meet the basic } \\
\text { standard of fishable and swimmable. }\end{array}$ \\
\hline & $\begin{array}{l}\text { Public Health Service Act or Safe Drinking Water Act (SDWA), } 42 \text { USC } \\
\S \S 300 \text { f-300j-26. Provides for regulation of maximum contaminant levels } \\
\text { in drinking water. }\end{array}$ \\
\hline & $\begin{array}{l}\text { EPA administers several relevant non-regulatory management programs, } \\
\text { including the National Estuary Program, CWA } \S 319 \text { Watershed } \\
\text { Improvement Grants, and the Gulf of Mexico Program. }\end{array}$ \\
\hline Department of Agriculture & $\begin{array}{l}\text { The USDA's several conservation programs are concerned with and } \\
\text { provide assistance for improving the quality of air, soil, surface water, and } \\
\text { drinking water in agricultural systems. }\end{array}$ \\
\hline \multirow{3}{*}{$\begin{array}{l}\text { Department of Commerce, } \\
\text { National Oceanic and } \\
\text { Atmospheric Administration } \\
\text { (NOAA) }\end{array}$} & $\begin{array}{l}\text { Coastal Zone Management Act of } 1972 \text { (CZMA; } 16 \text { USC } \S 1452 \text { ) } \\
\text { established federal policy "to preserve, protect, develop, and where } \\
\text { possible to restore or enhance, the resources of the Nation's coastal zone } \\
\text { for this and succeeding generations," and "to encourage and assist the } \\
\text { states to exercise effectively their responsibilities in the coastal zone } \\
\text { through the development and implementation of management programs to } \\
\text { achieve wise use of the land and water resources of the coastal zone, } \\
\text { giving full consideration to ecological, cultural, historic, and esthetic } \\
\text { values as well as the needs for compatible economic development..." } \\
\text { Administered through } 34 \text { state programs and a network of National } \\
\text { Estuarine Research Reserves. }\end{array}$ \\
\hline & $\begin{array}{l}1990 \text { Coastal Zone Act Reauthorization Amendments (CZARA), } 16 \text { USC } \\
\S \S 1451-1465 \text { added a nonpoint source pollution (NPS) program to } \\
\text { CZMA. The purpose of these amendments is to develop and implement } \\
\text { control measures for NPS to restore and protect coastal waters in } \\
\text { collaboration with other state and local authorities. }\end{array}$ \\
\hline & $\begin{array}{l}\text { The National Marine Fisheries Service manages fisheries in federal waters } \\
\text { under the Magnuson-Stevens Fishery Conservation and Management Act } \\
\text { (MSFCMA; } 16 \text { USC } \S 1801-1884 \text { ), working through regional Fishery } \\
\text { Management Councils. }\end{array}$ \\
\hline $\begin{array}{l}\text { Department of the Interior, } \\
\text { Bureau of Ocean Energy } \\
\text { Management (BOEM) }\end{array}$ & $\begin{array}{l}\text { BOEM manages offshore (federal jurisdiction) energy and mineral } \\
\text { resources, including oil and gas leasing, renewable energy development, } \\
\text { and agreements for uses of marine minerals, such as sand for beach } \\
\text { nourishment }\end{array}$ \\
\hline
\end{tabular}


Table 1. Cont.

\begin{tabular}{l|l}
\hline Lead Agency & Policies and programs \\
\hline $\begin{array}{l}\text { Department of the Interior, } \\
\text { USA Geological Survey } \\
\text { (USGS) }\end{array}$ & $\begin{array}{l}\text { The National Water-Quality Assessment Program (NAWQA) conducts } \\
\text { extensive monitoring and assessment of USA waters. The USGS also } \\
\text { conducts a wetlands research program. }\end{array}$ \\
\hline $\begin{array}{l}\text { Department of the Interior, } \\
\text { USA Fish and Wildlife } \\
\text { Service (FWS) }\end{array}$ & $\begin{array}{l}\text { The FWS is a partner with NOAA and EPA in administering provisions of } \\
\text { the CWA and the Endangered Species Act. Coastal, wetland, and habitat } \\
\text { programs in USFWS support and contribute to the science and } \\
\text { management of the Gulf coast. }\end{array}$ \\
\hline $\begin{array}{l}\text { Department of the Interior, } \\
\text { USA Park Service }\end{array}$ & $\begin{array}{l}\text { The Park Service's Gulf Islands and Padre Island National Seashores } \\
\text { protect and manage large areas of barrier islands and adjacent waters in } \\
\text { Florida, Mississippi and Texas; Everglades and Dry Tortugas National } \\
\text { Parks include large extents of Gulf shores. }\end{array}$ \\
\hline $\begin{array}{l}\text { USA Army Corps of } \\
\text { Engineers (ACOE) }\end{array}$ & $\begin{array}{l}\text { The ACOE Civil Works programs include water resource development } \\
\text { activities: flood risk management, navigation, recreation, infrastructure, } \\
\text { environmental stewardship, and emergency response. }\end{array}$ \\
\hline Other agencies & $\begin{array}{l}\text { The USA Forest Service, Bureau of Land Management, and Department } \\
\text { of Defense have major roles in land and water use and conservation in the } \\
\text { Gulf of Mexico coastal zone. }\end{array}$ \\
\hline
\end{tabular}

\subsection{Regional Entities}

Several regional organizations have important roles related to the sustainability of the Gulf Coast environment and its resources. The Gulf States Marine Fisheries Commission has regulatory authority (through the states) for managing interstate fisheries in inshore waters of the Gulf of Mexico, and can establish annual catch limits and restrictions on harvesting. Likewise, the Gulf of Mexico Fishery Management Council regulates and manages fisheries in offshore federal waters, under the authority of the National Marine Fisheries Service, USA Department of Commerce. Neither agency has the authority to regulate chemical uses that cause risks to fish, shellfish or their prey, or to prevent physical alteration and destruction of critical habitats, although they act in an advisory capacity, and may urge action by a state environmental agency, the USA Environmental Protection Agency, or the USA Army Corps of Engineers.

In addition to these regional regulatory bodies, several non-governmental bodies act to prioritize, facilitate, fund and coordinate actions at the regional level. The Gulf of Mexico Alliance (GOMA [12]), as a major example, is a partnership founded by the governors of Alabama, Florida, Louisiana, Mississippi and Texas, with support and technical assistance from several federal agencies. The goal of GOMA is "...increasing regional collaboration to enhance the ecological and economic health of the Gulf of Mexico." The GOMA's priority action areas are water quality; habitat conservation and restoration; ecosystem integration and assessment; nutrients and nutrient impacts; coastal community resilience; and environmental education. The partnership has made progress in harmonizing actions and communication among states, federal agencies, NGOs and the private sector. More recently, The Gulf Coast Ecosystem Restoration Council was formed under the Restore Act of 2012 to coordinate funding of restoration actions in response to the Deepwater Horizon oil disaster of 2010. The Restore 
Act provides that $80 \%$ of damages recovered from the responsible parties are to be allocated for activities that contribute to the environmental and economic well-being of the Gulf coast and its residents; portions of the allocation will be administered by the Council and portions by the states. The Council is chaired by the USA Secretary of Commerce, and includes the five Gulf state Governors along with the principals of relevant federal agencies.

\subsection{States}

The five states that bound the USA Gulf Coast share interests in maintaining clean beaches, productive fisheries, diverse intact habitats to support fish and wildlife, thriving maritime industries, and community resilience to extreme events and sea level rise. Nevertheless, these and other relevant interests vary from state to state in degree and character, as do governance structures, policy environments, and relative importance of the coast, both geographically and economically. To illustrate similarities and differences among the states, we summarized information from each of their coastal zone management programs (Table 2). The USA Coastal Zone Management Act authorizes a framework and funding for coastal states with federally approved programs to "preserve, protect, develop, and where possible, to restore or enhance the resources of the nation's coastal zone" (16 USC $\S 1451)$

Table 2. Gulf states coastal zone management programs, with lead agency, stated areas of priority, responsibility or activity, and $\mathrm{km}$ of Gulf shoreline including estuaries and other coastal water bodies $[13,14]$.

\begin{tabular}{|c|c|c|}
\hline State & Lead Agency and priorities & $\begin{array}{l}\text { Length of Gulf } \\
\text { coastline (km) }\end{array}$ \\
\hline Texas & $\begin{array}{l}\text { Texas General Land Office, Coastal Management Agency } \\
\text { Coastal natural hazards response } \\
\text { Critical areas enhancement } \\
\text { Public access } \\
\text { Waterfront revitalization and ecotourism development } \\
\text { Permit streamlining/assistance, governmental coordination and local } \\
\text { government planning assistance } \\
\text { Water [and] sediment quality and quality improvements }\end{array}$ & 5408 \\
\hline Louisiana & $\begin{array}{l}\text { Department of Natural Resources, Coastal Management Program } \\
\text { Coastal Use Guidelines } \\
\text { Coastal Use Permit Program } \\
\text { Coastal Nonpoint Pollution Control Program } \\
\text { Wetland mitigation } \\
\text { Local delegation (to parishes) }\end{array}$ & 12,431 \\
\hline Mississippi & $\begin{array}{l}\text { Department of Marine Resources, Office of Coastal Zone Management } \\
\text { Coastal Reserves Program } \\
\text { Wetlands permitting } \\
\text { Special projects }\end{array}$ & 578 \\
\hline
\end{tabular}


Table 2. Cont.

\begin{tabular}{|c|c|c|}
\hline State & Lead Agency and priorities & $\begin{array}{l}\text { Length of Gulf } \\
\text { coastline (km) }\end{array}$ \\
\hline Alabama & $\begin{array}{l}\text { Department of Conservation and Natural Resources, Department } \\
\text { of Environmental Management } \\
\text { Watershed planning } \\
\text { Water quality monitoring } \\
\text { Coastal hazard mitigation } \\
\text { Public access } \\
\text { Public outreach }\end{array}$ & 977 \\
\hline Florida & $\begin{array}{l}\text { Department of Environmental Protection } \\
\text { Wetlands } \\
\text { Coastal hazards } \\
\text { Public access } \\
\text { Marine debris } \\
\text { Cumulative and secondary impacts } \\
\text { Special area management planning } \\
\text { Ocean resources } \\
\text { Energy and government facility siting } \\
\text { Aquaculture } \\
\text { Community resiliency: planning for sea level rise } \\
\text { Coral and hard bottom ecosystem mapping, monitoring, and } \\
\text { management } \\
\text { Estuarine habitat restoration } \\
\text { Special area management planning for critical wildlife areas } \\
\text { Marine debris and aquaculture use zones } \\
\text { Aquatic preserve management plans }\end{array}$ & $\sim 6400^{*}$ \\
\hline
\end{tabular}

${ }^{*}$ Estimated from total (Gulf and Atlantic) Florida coastline.

\subsection{Localities}

The USA Gulf of Mexico is bordered by 56 counties and parishes, a few large metropolitan areas, and hundreds of municipalities. It is beyond the scope of this article to discuss in detail the structural and functional aspects of local governance; we offer only a few general observations.

Although they are at the bottom of the governance hierarchy, localities are ultimately responsible for vast numbers of decisions that affect the environment and contribute positively or negatively to sustainability. Even under numerous constraints imposed by federal and state policies, local governments have considerable authority and influence in such decisions as land planning and permitting, infrastructure development, water and waste management, maintenance of seaports, and many other activities affecting coastal resources. It is notable in this context that Louisiana has delegated its coastal zone management program to coastal parishes.

Another, intermediate layer of governance pertains when localities form partnerships to address common environmental problems, or those that overlap local jurisdictions [15,16]; spatial overlap is a common situation in managing coastal resources [17]. Some of these partnerships may be represented by local participation in the large regional entities discussed above; others are more local, for example, 
the Tampa Bay Regional Planning Council (TBRPC [18]). Members of the TBRPC include 21 municipalities, four counties, state agency representatives, and gubernatorial appointees. Although the scope of TBRPC is comprehensive and not focused solely on the environment or coastal resources, it has contributed significantly to the restoration, maintenance, and future conservation of the Tampa Bay environment, both directly and through its partnership with the multi-jurisdictional Tampa Bay Estuary Program (TBEP [19]).

Thus, the policy environment of the Gulf coast is rooted in the federal-state-local government hierarchy, but also branches into various distributed networks at scales ranging from individual estuaries (National Estuary Programs [20]) to the entire coast, as with the Gulf of Mexico Alliance and the Gulf Coast Ecosystem Restoration Council (Figure 1). Although the focus of this special issue and this article is on government policy, the roles of these networks in coordination, communication, funding, and influencing policy must be acknowledged as having major implications for sustainability.

In the following section, we examine three cases from a sustainability perspective, with topics ranging from urban planning and development to conservation of habitats and biodiversity. Our goal is to consider how the policies that pertain to these diverse, but often interdependent, activities and phenomena have led to successes, failures, or mixed results, and what we can learn from these examples.

Figure 1. Generalized policy structure for the USA Gulf of Mexico coastal zone. Gray boxes and heavy lines show the governmental hierarchy; white boxes and thin lines show network institutions and organizations. Many actual or potential linkages are not shown for the purpose of clarity. DOD: Department of Defense; DOE: Department of Energy; DOI: Department of the Interior; EPA: Environmental Protection Agency; NOAA: National Oceanic and Atmospheric Administration; CZM: Coastal Zone Management Programs; GCERC: Gulf Coast Ecosystem Restoration Council; GOMA: Gulf of Mexico Alliance; GMFMC: Gulf of Mexico Fishery Management Council; GSMFC: Gulf States Marine Fisheries Commission; NEPs: National Estuary Programs; NGOs: non-governmental organizations (e.g., The Nature Conservancy).

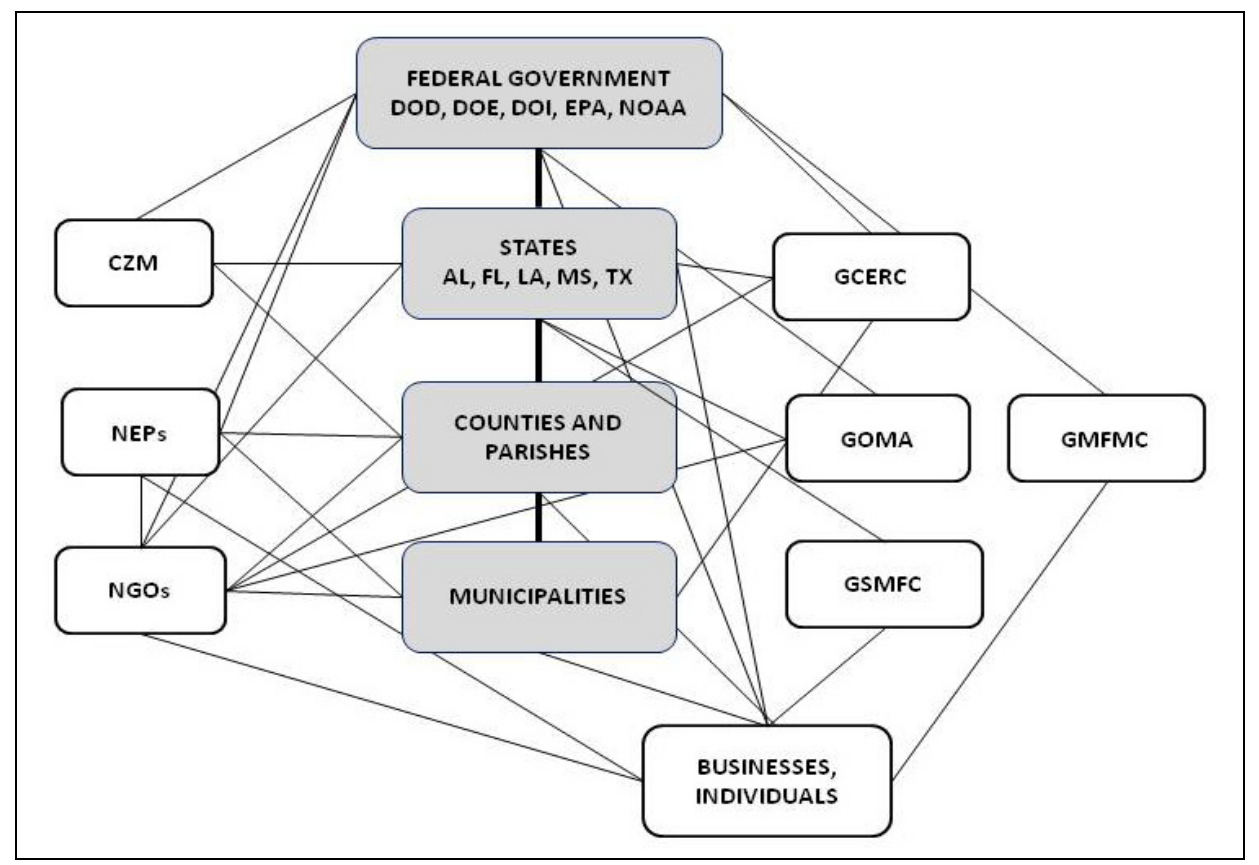




\section{Discussion of Case Studies}

\subsection{Tampa Bay: Present Successes and Future Risks}

In the late 1960s and early 1970s, water quality in Tampa Bay, a large estuary on the Florida Gulf Coast, was observed to be deteriorating, with increasing nutrient and chlorophyll a concentrations, decreased water transparency, and loss of seagrasses [21,22]. Unchecked, these trends could have led to more serious eutrophication, along with undesirable and potentially irreversible changes to the estuary's ecosystem, as occurred in Chesapeake Bay beginning in the mid-20th century [23]. The primary cause of the problem at the time was discharge of poorly treated sewage from the city of Tampa. As a result of action by citizens' groups and support from the federal government, Tampa installed advanced wastewater treatment that greatly reduced discharges of nitrogen into the bay. This action was followed by major reductions in other point sources of nutrients, along with efforts to prevent losses of mangrove and tidal marsh habitats to development and to restore them where possible [21]. Improvements in water quality and seagrass coverage were apparent within a few years. The majority of nitrogen loading to Tampa Bay, although much reduced overall, shifted from point sources to non-point sources by the 1990s [24].

By 2011, seagrass coverage in Tampa Bay had increased dramatically, tidal wetlands had shown a substantial net increase over the 1995 extent, and water quality had improved to 1950s levels-all achieved in the face of a four-fold population increase in the watershed [25].

The successes in Tampa Bay are regarded as an exception to the less satisfactory performance of several other estuary programs [26]. Although there are geophysical factors that contribute to positive responses to nutrient reductions in Tampa Bay (e.g., weak stratification, relatively low inflow from the watershed), coupled with the dominance of point sources over diffuse sources, the policy environment has been and continues to be a key factor. The initial responses were reactive, but the problems were recognized early, and effective actions were taken. Challenges for the future - climate change, sea level rise, and a projected doubling of population by 2050 - are being addressed proactively and comprehensively by a diverse, regional network of stakeholders and authorities [27].

In the Tampa Bay case, citizen action combined with government funding for water infrastructure, along with regulatory limitations on pollutant discharges from wastewater treatment facilities (i.e. state implementation of federal policy under the Clean Water Act), contributed to an early, effective response. Subsequently, a strong regional policy network, the TBRPC, was established, followed by development of the TBEP, an embedded network [20] focused on coordinating government and private actions to improve conditions in the Bay and prevent future degradation. In this example, we suggest that hierarchical government policies (Clean Water Act, state water quality standards, and municipal infrastructure) worked together with - and were potentiated by-non-governmental actions, and that regional networks were essential to achieving positive outcomes. Whether the institutional networks and policy structures that have been successful so far will continue to forge a sustainable trajectory remains to be seen. 


\subsection{Coastal Louisiana: What Is Sustainable?}

High rates of land loss in coastal southern Louisiana, as much as $100 \mathrm{~km}^{2} /$ year in recent decades, have been widely reported, e.g., [28,29], as have the effects of flooding and displacement on coastal communities and ecosystems. Another $4500 \mathrm{~km}^{2}$ of coastal wetlands could be lost over the next 50 years without significant preventive actions [30]. The proximal cause of land and wetland conversion to open water is relative sea level rise, a combination of increasing ocean volume and land subsidence. More fundamental causes include climate change, engineering of the Mississippi River, its distributaries and flood plain for navigation and flood control, and subsidence caused by tectonic forces with some contribution from petroleum extraction [28,30]. Over the past two decades, a series of plans has been developed and numerous projects have been undertaken in attempts to combat the losses. Most recently, Louisiana has produced an updated version of its coastal master plan [29], emphasizing comprehensive, sustainable approaches to the land loss problem, including a variety of projects to protect or restore coastal lands: structural protection, bank stabilization, oyster reef construction, ridge restoration, shoreline protection, barrier island restoration, marsh creation, sediment diversion, and hydrologic restoration. A common theme among plans and analyses over the years has been the lack of comprehensive, coordinated governance that could have lessened the deterioration of the coastal zone. The interests of navigation, flood control, commercial fishing, the petroleum industry, coastal communities, and sustainable ecosystems not only can be divergent, but also are governed by an array of different agencies with different missions, mandates, priorities, and constituencies. Although a multitude of stakeholders was engaged in the development of the latest master plan [29], an effective governance network, specific to the Louisiana coast and comparable to the Tampa Bay example, apparently has not been instituted, nor planned.

The effectiveness of the new master plan remains to be seen, but we can consider some positive and negative forces that will influence the degree of its success. On the positive side, a large amount of new funding is expected to be available as a result of damages and penalties accruing from the 2010 Deepwater Horizon oil well blowout, as well as additional revenues from offshore oil leasing. When combined with existing funding, the total may begin to approach the scale necessary to significantly reduce and to some extent reverse coastal land losses. Moreover, a comprehensive plan is in place that promotes sustainability and a systems approach to harmonizing the various interests.

There are factors that call success into question, however. First, a recent unpublished analysis of data indicates that the rate of relative sea level rise along the Louisiana coast is twice that of the worst-case scenario in the master plan, more than $11 \mathrm{~mm} /$ year, or $0.4 \mathrm{~m}$ by the plan's 2050 horizon, and $>1 \mathrm{~m}$ by 2100 [31]. Much of the area under discussion is $<1 \mathrm{~m}$ above sea level. Second, the scale of the area at risk and the scope of the measures required to sustain the desired ecological, social, and economic values appear to be unprecedented in any previous restoration or reclamation effort; it is not clear that even greatly enhanced funding will be sufficient. Finally, there is the governance problem discussed above, which is likely to work against a systems approach unless it can be overcome. Indeed, the master plan does not address governance explicitly (it is implicit that the state will provide this function), although the need for federal, state and local coordination is acknowledged.

The heading of this section asks, "What is sustainable?" The Louisiana master plan acknowledges that complete restoration is not feasible, but takes the position that a well-funded, comprehensive 
systems-oriented approach can sustain the major ecological, social and economic values of the area, at least for the next few decades. The alternative to successful implementation of the plan predicts substantial losses - of infrastructure, commerce, traditional ways of life and cultures, natural resources and ecological values. Less than $1 \mathrm{~m}$ of relative sea level rise, likely within this century, will inundate much of coastal Louisiana despite protective measures. Would planning now for an orderly retreat be a rational course? We suggest that not to consider this contingency could lead to a serious failure of policy, foreshadowed by the aftermath of Hurricane Katrina. Katrina cost $>1,100$ lives in Louisiana [32] and $>\$ 200$ billion in damages [33]. The magnitude of these damages has been attributed to a combination of federal and local government policies that encouraged intensive development of flood-prone areas [33].

\subsection{Coastal Habitats, Biodiversity, and Fisheries}

Gulf of Mexico coastal ecosystems support abundant, diverse terrestrial and aquatic wildlife: migratory and resident species, freshwater, brackish and saltwater species, inland, coastal, and oceanic species mingle in the estuaries, wetlands, forests, and nearshore waters. These living resources supply benefits to humans that are significant at local, regional and national scales, including subsistence, tourism, recreational and commercial fisheries, and cultural values. Our discussion focuses on the strengths and weaknesses of policies affecting commercial fisheries.

Several species of commercially important fish and shellfish depend heavily on nearshore habitats for their productivity [34]. Shallow water, protected bays, marshes, and seagrass beds supply food and refuge from predation for vulnerable early life stages of such species as blue crab (Callinectes sapidus), white, pink, and brown shrimp (Litopenaeus setiferus, Farfantapenaeus duoarum, and F. aztecus), Eastern oyster (Crassostrea virginica), and Gulf menhaden (Brevoortia patronus). Besides being of major importance to fisheries, these species have crucial ecological roles as consumers of plankton, as prey for large fishes, and in the case of oysters, as habitat builders [34,35]. It has been reported that $95 \%$ of commercial harvest in the Gulf is dependent on these near-shore habitats [36].

The policy structure within which commercial fisheries are regulated is separate and quite different from the policy environment that pertains to critically important coastal habitats. Fisheries within state waters are regulated by the states under the authority of the five-state Gulf States Marine Fisheries Commission. Offshore fisheries are regulated by the Gulf of Mexico Marine Fishery Management Council, under the authority of the National Marine Fisheries Service. A detailed account of federal and state laws, regulations and governance related to these fisheries can be found in [36]. The fisheries management entities have made progress in recent years toward preventing overfishing and maintaining sustainable harvest levels for commercial fisheries. Despite many past failures, modern marine fisheries management in the USA and the Gulf of Mexico can be seen as a model of sustainability-oriented policy, but only if we ignore the problem of habitat loss. The goals of fishery management are essentially to balance natural resource, economic, and social elements to sustain the fish populations that support the fisheries. For example, one of the objectives of the Gulf Menhaden Management Plan [36] is clearly about sustainability: "To ascertain optimum benefits of the menhaden fishery...while perpetuating these benefits for future generations." At the same time, "One of the greatest long-term threats to the viability of commercial and recreational fisheries is the continuing loss of marine, estuarine, and other aquatic habitats. Habitat considerations should receive increased 
attention for the conservation and management of fishery resources of the United States." (MagnusonStevens Fishery Conservation and Management Act, as amended 1996, Public Law 94-265). Wetlands and other coastal aquatic habitats are governed under a variety of federal, state and local policies; relevant federal agencies and authorities can be found in Table 1, with a more detailed account in an EPA publication [11]. Several aspects of coastal habitat protection are included in the states' Coastal Zone Management Programs (Table 2). Despite regulatory and permitting requirements, coastal wetlands in the Gulf of Mexico region continue to be lost to human activities, with development and agriculture as major causes [37]. Other activities that can degrade habitats, such as dredging, shoreline armoring and dock construction, although generally requiring permits, continue to reduce the quality and quantity of habitats that support coastal fisheries [34]. The cumulative impacts of many such actions are widely acknowledged, and have been shown to pose long-term risks to the sustainability of major fisheries [17,38,39], but permits are granted piecemeal [37].

Fishery managers can apply a wide range of tools to control the magnitude, timing, location, method, species, etc., of harvests, based on substantial data and sophisticated models. Fishery management plans include comprehensive information on habitat requirements of harvested species, as well as the location and nature of "essential fish habitat." Yet, fishery management agencies play only advisory roles in determining the fate of critical habitats. The dilemma is that a multitude of actions that are largely managed at local scales can affect the sustainability of resources that are managed at Gulf-wide scales [17]. In theory, federal policies stemming from the Clean Water Act and the Coastal Zone Management Act could help to solve the problem of cumulative impacts, but much of the evidence is to the contrary [34,38]. A regional organization such as the Gulf of Mexico Alliance, with habitat as one of its priorities, might explore the potential for establishing a governance network analogous to the regional fishery management entities.

\section{Conclusions}

The three case studies illustrate various aspects of the relationships between government policies and sustainability of the Gulf of Mexico coast, primarily from a natural resources perspective (Table 3). We reviewed one case, Tampa Bay, that can be considered a success story; a second (coastal Louisiana) where the challenges to sustainability are so great that even the most effective policies may not suffice; and third, the case of coastal habitats that support fisheries, where there is a clear need for different, or additional, policy solutions. In Table 3 and the following discussion, we suggest some principles of environmental governance that can be inferred from this comparative analysis, and how these principles apply to the sustainability of coastal resources and ecosystems.

Geographic scale is one aspect of the policy-sustainability relationship. Although geographically and jurisdictionally complex, the Tampa Bay watershed is a compact area $\left(5617 \mathrm{~km}^{2}\right)$ relative to our other cases. The Louisiana coastal zone has several times this area, and the fisheries example pertains to the entire USA coast and coastal waters of the Gulf of Mexico, an area more than an order of magnitude greater than the Tampa Bay watershed. In the first case, the relevant policies are rather tightly focused on the quality and sustainability of the Tampa Bay ecosystem. In the second, although there is a decades-long history of comprehensive planning to ameliorate Louisiana's land loss problem, in practice the efforts appear to be fragmented into a focus on individual projects (e.g., for wetland 
restoration, barrier island rebuilding, flood protection). In the fishery-habitat case we illustrate the gross mismatch between the scale of fishery management, which is well-aligned with biological and economic realities, and the scale of preventing negative impacts to critical habitats, which is almost entirely local and site-specific-in effect, blind to these realities.

Policies that favor sustainability must deal effectively with the complexities of environmental, economic, and social systems. For Tampa Bay, focus on the bay itself has proved to be an integrator of policy in favor of environmental sustainability; maintaining the quality of this environment in a rapidly growing urban complex has brought together numerous political jurisdictions and economic interests in the interest of a common cause. In contrast, the currently unsustainable trajectory of the Louisiana coast is at least partially the result of persistent failures to address the complexities of environmental change in the context of competing economic and social interests. For the fisheries case, the most severe effect of complexity arises from the hierarchical policy structure that hinders effective habitat conservation and favors narrow, short-sighted, local decisions.

Table 3. Summary of case studies: how selected aspects relate to government policies and sustainability.

\begin{tabular}{|c|c|c|c|c|}
\hline Aspect & Tampa Bay & Louisiana coast & $\begin{array}{l}\text { Commercial } \\
\text { fisheries and } \\
\text { habitat }\end{array}$ & $\begin{array}{l}\text { Relationships to } \\
\text { sustainability and } \\
\text { policy }\end{array}$ \\
\hline $\begin{array}{l}\text { Relative } \\
\text { geographic } \\
\text { size }\end{array}$ & Small & Medium & Large & $\begin{array}{l}\text { Ease of focus at finer } \\
\text { scales }\end{array}$ \\
\hline $\begin{array}{l}\text { Geographic } \\
\text { focus }\end{array}$ & $\begin{array}{l}\text { Tightly focused } \\
\text { on the Tampa } \\
\text { Bay ecosystem }\end{array}$ & $\begin{array}{l}\text { Comprehensive focus of } \\
\text { planning tends to be } \\
\text { dispersed toward } \\
\text { individual projects }\end{array}$ & $\begin{array}{l}\text { Gulf-wide for } \\
\text { fisheries; site- } \\
\text { specific for habitat }\end{array}$ & $\begin{array}{l}\text { Geographic focus leads } \\
\text { to more integrated } \\
\text { policies and policy } \\
\text { applications }\end{array}$ \\
\hline $\begin{array}{l}\text { Relative } \\
\text { complexity }\end{array}$ & Moderate & Great & Great & $\begin{array}{l}\text { Complexity } \\
\text { complicates policy } \\
\text { solutions }\end{array}$ \\
\hline $\begin{array}{l}\text { Dominant } \\
\text { stressors }\end{array}$ & $\begin{array}{l}\text { Nitrogen } \\
\text { loading; } \\
\text { population } \\
\text { growth; climate } \\
\text { change }\end{array}$ & $\begin{array}{l}\text { Sea-level rise; coastal } \\
\text { storms; climate change }\end{array}$ & $\begin{array}{l}\text { Habitat loss and } \\
\text { degradation; climate } \\
\text { change; fishing } \\
\text { pressure }\end{array}$ & $\begin{array}{l}\text { Scale, and ease or } \\
\text { difficulty of control }\end{array}$ \\
\hline Temporal & Proactive & Reactive & Mostly proactive & $\begin{array}{l}\text { Proactive policies are } \\
\text { required for } \\
\text { sustainability }\end{array}$ \\
\hline $\begin{array}{l}\text { Governance } \\
\text { structures }\end{array}$ & Network & Hierarchy & $\begin{array}{l}\text { Network for } \\
\text { fisheries; } \\
\text { hierarchical for } \\
\text { habitat }\end{array}$ & $\begin{array}{l}\text { Networks tend to foster } \\
\text { sustainable solutions }\end{array}$ \\
\hline
\end{tabular}


Sustainability requires policies oriented toward the future, yet in some of our examples and more broadly, government policy-making tends to be reactive. In the coastal environment, there has been far more emphasis and funding directed toward restoration (reactive) than toward protection (proactive). The Louisiana example demonstrates that proactive policies could have prevented much of the damage that has occurred from storms and land loss, yet society is now contributing tens of billions of dollars for restoration projects that may provide only temporary relief. The Tampa Bay case is a counter-example; although initially reactive, the policy environment soon became proactive, with the result that much harm to the environment has been and likely will continue to be prevented. The policies that govern fishery management and habitat protection in the coastal zone are inherently proactive - most of the failures have been in implementation. We suggest that national and regional efforts are needed to close the policy gap for protection of critical coastal habitats against the cumulative effects of many local actions.

Federal environmental policies favor sustainability, as in the examples of the National Environmental Policy Act, Clean Water Act, Coastal Zone Management Act, and Magnuson-Stevens Fishery Conservation and Management Act. Nonetheless, these policies are implemented through governance structures that may or may not support sustainable outcomes. Our case studies present contrasts between hierarchical and networked governance structures; effective networks seem to favor successful governance of complex regional issues. Federal legislation has made positive contributions to the establishment of governance networks by authorizing and funding Coastal Zone Management Programs, National Estuary Programs, interstate fishery management commissions, and regional fishery management councils. A deeper exploration of how networks and policies that support them could contribute to sustainability would be worthwhile [20].

In the Introduction, we posited an analogy between environmental health and human well-being. This connection is implicit in each of the case studies. A eutrophic, sewage-polluted Tampa Bay would present risks to human health, be detrimental to recreation and fisheries, and generally reduce the quality of life and economic potential of the area. In the Louisiana example, if sustainability is not achieved, coastal land loss will continue to cause displacements of people and communities, economic losses, and social stresses, all to the detriment of human well-being. Marine fisheries that depend on sustainable coastal habitats have economic, nutritional, cultural, and recreational benefits that will be diminished or lost along with the habitats in the absence of effective, scalable policy and governance structures. We do not attempt a deeper analysis of these connections (and doubt that it would be supported by the extant literature), but the examples illustrate the dependence of human well-being on the sustainability and integrity of coastal ecosystems, which in turn depend upon effective policies and governance structures. In Figure 2, we offer a schematic view of these aspects of the relationships between policy, governance, and the three pillars of sustainability, including human well-being.

Sustainability, as measured by appropriate indicators, could be a benchmark, serving as a null hypothesis for testing a vision of future management of coastal resources against current policies and alternatives [40]. To this end, advances in modeling and prediction of complex systems are providing more power to evaluate scenarios and trade-offs [41]. In the governance realm, a paradigm shift may be underway: an evolution from traditional regulatory regimes toward more participatory, consensus, and networked structures. Climate change, sea level rise, and the demands brought on by population growth are global challenges to the sustainability of coastal resources for future generations. 
Sustainability can be more than a vision, it can be an organizing principle for more efficient and effective policies and governance in the coastal zone and beyond [42].

Figure 2. Relationships between policy, governance and sustainability, suggesting that proactive policies, network governance structures, and appropriate scaling of governance favor sustainability.

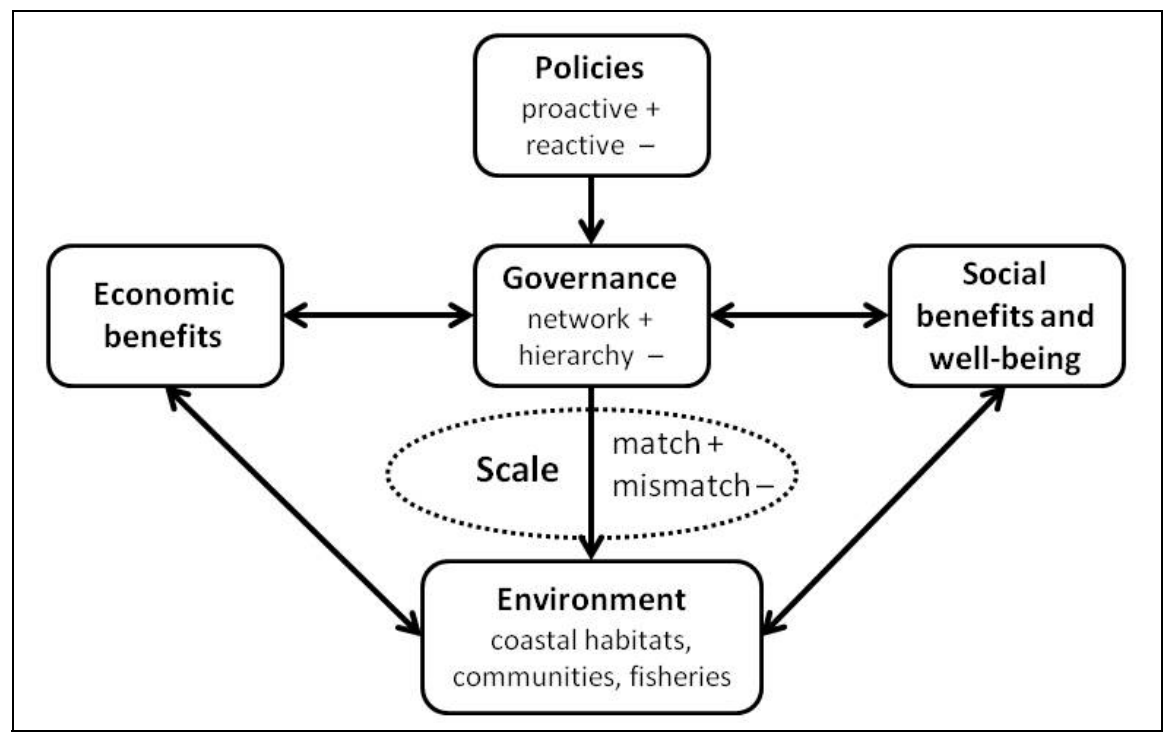

\section{Acknowledgments}

We appreciate comments on drafts of this article by Jana Compton, Marc Russell, and two anonymous peer reviewers. The views expressed in this article are those of the authors and do not necessarily reflect the views or policies of the USA Environmental Protection Agency.

\section{Conflicts of Interest}

The authors declare no conflict of interest.

\section{References and Notes}

1. Bowen, R.E.; Riley, C. Socio-economic indicators and integrated coastal management. Ocean Coast. Manage. 2003, 46, 299-312.

2. Jordan, S.J.; Summers, J.K. Environmental Sustainability, Ecosystem Services, and Human Well-Being. In Praeger Handbook of Environmental Health; Friis, R.H., Ed.; Praeger: Santa Barbara, CA, USA, 2012; pp. 569-587.

3. Garmestani, A.S.; Allen, C.R.; Benson, M.H. Can law foster social-ecological resilience? Ecol. Soc. 2013, 18, 37.

4. Miranda, L.M.; Mohai, P.; Bus, J.; Charnelry, G.; Dorward-King, E.J.; Foster, P; Munns, W.R., Jr. Policy Concepts and Applications. In Inter-Connections Between Human Health and Ecological Integrity; di Giulio, R.T., Benson, W.H., Eds.; SETAC Press: Pensacola, FL, USA, 2002; pp. 15-41.

5. Sidle, R.C.; Benson, W.H.; Carriger, J.F.; Kamai, T. Broader perspective on ecosystem sustainability: Consequences for decision making. Proc. Natl. Acad. Sci. USA 2013, 110, 9201-9208. 
6. Gregory, R.; Failing, L.; Harstone, M.; Long, G.; McDaniels, T.; Ohlson, D. Structured Decision Making: A Practical Guide to Environmental Management Choices; Wiley-Blackwell: West Sussex, UK, 2012; p. 299.

7. Colgan, C.S. Living near... and making a living from... the nation's coasts and oceans. Available online: http:/govinfo.library.unt.edu/oceancommission/documents/prelimreport/append_c.pdf. (accessed on 31 October 2013).

8. McDaniels, T.; Longstaff, H.; Dowlatabadi, H. A value-based framework for risk management decisions involving multiple scales: a salmon aquaculture example. Environ. Sci. Policy 2006, 9 , $423-438$.

9. Carriger, J.F.; Benson, W.H. Restoring and managing Gulf of Mexico fisheries: A path toward creative decision-making. In Estuaries: Classification, Ecology, and Human Impacts; Jordan, S.J., Ed.; NOVA Science Publishers, Inc.: Hauppauge, NY, USA, 2011; pp. 291-334.

10. Skocpol, T. States and Social Revolutions; Syndics of the Cambridge University Press: Cambridge, MA, USA, 1979; p. 407.

11. Coastal Wetlands Initiative: Gulf of Mexico. Available online: http://www.habitat.noaa.gov/ media/news/pdf/gulf-of-mexico-review_final.pdf (accessed on 31 October 2013).

12. Gulf of Mexico Alliance. Available online: http://www.gulfofmexicoalliance.org (accessed on 31 October 2013).

13. Final Assessment and Strategies, FY 2011-FY 2015. Available online: http://www.dep.state.fl.us/ cmp/links/files/FY2011-2015_Section309_Assessment_Strategies_revMay_6_2013_Final.pdf (accessed on 31 October 2013).

14. National Oceanic and Atmospheric Administration, Ocean and Coastal Resource Management. Available online: http://coastalmanagement.noaa.gov/mystate/welcome.html (accessed on 13 August 2013).

15. Lubell, M.; Schneider, M.; Scholz, J.T.; Mete, M. Watershed partnerships and the emergence of collective action institutions. Am. J. Pol. Sci. 2002, 46, 148-163.

16. Feiock, R.C. Rational choice and regional governance. J. Urban Affairs 2007, 29, 47-63.

17. Jordan, S.J.; O’Higgins, T.; Dittmar, J.A. Ecosystem services of coastal habitats and fisheries: multi-scale ecological and economic modeling. Mar. Coast. Fish. 2012, 4, 573-586.

18. Tampa Bay Regional Planning Council. Available online: http://www.tbrpc.org (accessed on 31 October 2013).

19. Tampa Bay Estuary Program. Available online: http://www.tbep.org (accessed on 31 October 2013).

20. Schneider, M.; Scholz, J.; Lubell, M.; Mindruta, D.; Edwardsen, M. Building consensual institutions: Networks and the National Estuary Program. Am. J. Pol. Sci. 2003, 1, 143-158.

21. Lewis, R.R.; Clark, P.A.; Fleming, W.K.; Greening, H.S.; Johansson, R.O. The rehabilitation of the Tampa Bay Estuary, Florida, USA, as an example of successful integrated coastal management. Mar. Poll. Bull. 1999, 37, 468-473.

22. Janicki, A.; Pribble, R.; Janicki, S.; Winowitch, M. An analysis of long-term trends in Tampa Bay water quality. Available online: http://tampabay.wateratlas.usf.edu/upload/documents/ AnalysisLongTermTrendsTampWaterQuality.pdf (accessed on 31 October 2013). 
23. Kemp, W.M.; Boynton, W.R.; Adolf, J.E.; Boesch, D.E.; Boicourt, W.C.; Brush, G.; Cornwell, J.C.; Fisher, T.R.; Glibert, P.M.; Hagy, J.D.; et al. Eutrophication of Chesapeake Bay: Historical trends and Ecological interactions. Mar. Ecol. Prog. Ser. 2005, 303, 1-29.

24. Greening, H.; Janicki, A. Toward reversal of eutrophic conditions in a subtropical estuary: Water quality and seagrass response to nitrogen loading reductions in Tampa Bay, Florida, USA. Environ. Manage. 2006, 38, 163-178.

25. A Tampa Bay Estuary Program Progress Report. Available online: http://www.tbep.org/pdfs/ tbep_state_of_bay_2012_ptr_reduced.pdf(accessed on 31 October 2013).

26. Duarte, C.M.; Conley, D.J.; Carstensen, J.; Sánchez-Camacho, M. Return to Neverland: Shifting baselines affect eutrophication restoration targets. Est. Coasts 2009, 32, 29-36.

27. Evaluation and Appraisal Report of the Strategic Regional Policy Plan. Available online: http://www.tbrpc.org/srpp/pdf/SRPP\%20EAR\%20DRAFT\%208-8-11.pdf (accessed 31 October 2013).

28. Day, J.W., Jr.; Boesch, D.F.; Clairain, E.J.; Kemp, G.P.; Laska, S.B.; Mitsch, W.J.; Orth, K.; Mashriqui, H.; Reed, D.J.; Shabman, L.; et al. Restoration of the Mississippi Delta: Lessons from Hurricanes Katrina and Rita. Science 2007, 315, 1679-1684.

29. Louisiana's Comprehensive Master Plan for a Sustainable Coast. Available online: http://www.lacpra.org/assets/docs/2012\%20Master\%20Plan/Final\%20Plan/2012\%20Coastal\%20M aster\%20Plan.pdf (accessed on 31 October 2013). (please check the link)

30. González, J.L.; Törnqvist, T.E. Coastal Louisiana in crisis: Subsidence or sea level rise? Eos 2006, 87, 493-508.

31. New research: Louisiana coast faces highest rate of dea-level rise worldwide. Available online. http://thelensnola.org/2013/02/21/new-research-louisiana-coast-faces-highest-rate-of-sea-level-riseon-the-planet/ (accessed on 31 October 2013).

32. Jonkman, S.N.; Maaskant, B.; Boyd, E.; Levitan, M.L. Loss of life caused by the flooding of New Orleans after Hurricane Katrina: Analysis of the relationship between flood characteristics and mortality. Risk Anal. 2009, 5, 676-698.

33. Burby, R.J. Hurricane Katrina and the paradoxes of government disaster policy: Bringing about wise governmental decisions for hazardous areas. Ann. Am. Acad. Pol. Soc. Sci. 2006, 604, 171-191.

34. Peterson, M.S.; Lowe, M.R. Implications of cumulative impacts to estuarine and marine habitat quality for fish and invertebrate resources. Rev. Fish. Sci. 2009, 17, 505-523.

35. Jordan, S.J.; Peterson, M.S. Contributions of estuarine habitats to major fisheries. In Estuaries: Classification, Ecology and Human Impacts; Jordan, S.J., Ed.; Nova Science Publishers, Inc.: New York, NY, USA, 2011; pp. 75-91.

36. The Menhaden Fishery of the Gulf of Mexico, United States: A Regional Management Plan. Available online: http://www.gsmfc.org/publications/GSMFC\%20Number\%20099.pdf (accessed on 31 October 2013).

37. Brody, S.D.; Davis, S.E.; Highfield, W.E.; Bernhardt, S.P. A spatial-temporal analysis of Section 404 wetland permitting in Texas and Florida: Thirteen years of impact along the coast. Wetlands 2008, 1, 107-116.

38. Peterson, M.S. A conceptual view of environment-habitat-production linkages in tidal river estuaries. Rev. Fish. Sci. 2003, 11, 291-313. 
39. Jordan, S.J.; Smith, L.M.; Nestlerode, J.A. Cumulative effects of coastal habitat alterations on fishery resources: toward prediction at regional scales. Ecol. Soc. 2009, 14, 16.

40. Jordan, S.J. Sustainability-What are the odds? Envisioning the future of our environment, economy and society. Humanities 2013, 2, 119-127.

41. Christensen, V. Ecological networks in fisheries: Predicting the future? Fisheries 2013, 38, 76-81.

42. National Research Council. Sustainability for the Nation: Resource Connections and Governance Linkages; The National Academies Press: Washington, DC, USA, 2013; p. 142.

(C) 2013 by the authors; licensee MDPI, Basel, Switzerland. This article is an open access article distributed under the terms and conditions of the Creative Commons Attribution license (http://creativecommons.org/licenses/by/3.0/). 